\title{
Does Availability Bias Have Influence on FMCG Investors? An Empirical Study on Cognitive Dissonance, Rational Behaviour and Mental Accounting Bias
}

\author{
Shantha Gowri B ${ }^{1} \&$ Vedantam Seetha Ram $^{2}$ \\ ${ }^{1}$ VIT Business School, Vellore Institute of Technology, Tamilnadu, India \\ ${ }^{2}$ Dept of Technology Management, SMEC, Vellore Institute of Technology, Vellore Tamilnadu, India \\ Correspondence: Shantha Gowri B, Vellore Institute of Technology, VIT Business School, 632014, Vellore \\ Tamilnadu, India.
}

Received: June 3, 2019

Accepted: June 27, 2019

Online Published: June 30, 2019

doi:10.5430/ijfr.v10n4p68

URL: https://doi.org/10.5430/ijfr.v10n4p68

\begin{abstract}
Investors usually rely on the first-hand information to take their investment decisions. Investors are prone to many types of heuristics and bias which can lead to indecisive situations or irrational behavior and affect their performance. Indecisive state of mind of investors is attributed due to cognitive dissonance as it differs from their belief and the facts they come in reality. Mental accounting has its own advantages of meeting the investor's goal on time and allocating resources effectively to achieve each of their investment objectives, on the contrary it can also lead to poor portfolio management and performance. The current study is conducted in order to understand the influence of availability heuristic influence on cognitive dissonance and rational behavior through mental accounting bias as a mediating factor exclusively on Fast Moving Consumer Goods (FMCG) investor's decision making in stock market. Data was collected by purposive sampling method using self-administered questionnaire from 614 FMCG investors through 15 stock broking firms registered in Hyderabad city, tools like correlation, analysis of variance, Cronbach Alpha test, linear regression and mediation are used for data analysis. The results reveal that availability bias, cognitive dissonance and rational behavior are highly correlated to one another. Availability bias influence on cognitive dissonance and rational behavior of FMCG investors through mental accounting bias is negligible. Though many studies have accepted the major role played by mental accounting bias and few against it in our study it is proved to be negligible in case of defensive sectors of FMCG investors.
\end{abstract}

Keywords: availability bias, confirmation bias, cognitive dissonance, rational behavior, mental accounting bias, FMCG investors, mediation

\section{Introduction}

Behavioral finance integrates psychology with finance as it deals with humans and need to comprehend the behavior of individual investors in the stock market. It is the individual investors who make investment decisions in the market who are different in terms of age, experience, term of investment, risk and investment objective. Investors decisions also changes from time to time and place to place but overall they are affected by both emotional and cognition impact which lead to many biased behavior and influence their decision making (Ackert, Church \& Deaves, 2003).

Stock markets are sophisticated with erratic price changes which is always inexplicable and highly volatile which demands investors to be quick enough to take decisions as to buy, sell or hold on to the stocks especially, when prices are increasing or decreasing. Investors after being exposed to financial market news, expert's opinion and group behavior face undue pressure and stress to act immediately, as they are bombarded with tons of information leading to irrational and impulsive decisions by them.

Heuristics comes to rescue of the investors undue pressure, as they aim to solve problems or self-explore by exercising cognitive and more sensible approach even though, it is not assured to be reasonable, accurate, and realistic. It is usually recommended in circumstances when one cannot find the feasibility of arriving at the best possible answer. Instead, it can prove to be adequate enough for realization of an immediate need by quickening the decision making and intellectual thinking process, which is usually time consuming. 
Representative bias, availability and anchoring are the different types of heuristics which affect investor's decisions and selection of stocks. Similarly, investors are influenced by various types of biases like overconfidence, herding, disposition, recency, ambiguity aversion, conservatism, endowment, hindsight, status quo, loss aversion, mental accounting and cognitive dissonance which influence the stock market movements and individual investor's investment decisions.

Investors prone to anchoring bias usually take blind folded decision based on their selective information they gather to support their own decisions. Further to accelerate the decision process they tend to imitate their co traders actions and follow the overall market behavior of herding though it is different from their own plan of action thus leads to cognitive dissonance and underreaction of information as anchoring and herding bias which makes an individual not to accept any new piece of information. This will determinate the investors stock selection and investment.

Investors rely on recent information of winning stocks as it grabs investors' attention and without re-examining they go for purchase of new stocks and convince themselves of having taken right decisions. The recency and overconfidence bias will hamper the overall portfolio performance and stock selection. Investors analyst prone to representative bias rely on expert opinion and recent news are announced as they are in a dilemma to take decision as to hold on or sell off the shares and when it falls feel bad that they should have sold during its uptrend. Sometimes investors arrive to a particular decision on their own but still are in a conflicting state of mind and take a different decision due to cognitive dissonance. Thus here heuristics and bias together affect retail investor's investment decisions, selection of stocks and impact the whole stock market.

Loss aversion bias enables the investor to play safe and dispose the well performing stocks without taking time or effort to confirm its reliability and follow the crowd psychology of herding bias., hold on during times of uncertainty and feel bad later if the price increases, makes decisions learnt from their past loss experiences which affects his overall portfolio performance.

Investors prone to availability bias take news as an assurance and invest in new company stocks which are performing well recently and bought by majority of them in the market, hold on expecting the prices to increase though it is in its uptrend thus affecting their investment decision making and portfolio selection of retail investors.

Herding further acts as a confirmation bias to the anchored information and increase the pace of decision making if he observes others also to move in same direction. Their perception becomes strong when the overall investor behavior and co traders also act in the same way. This behavior affects the stock market during bull times motivates the investors to go for profit booking and gradually leads to bearish market as price starts to decline as the stock market experience mass selling.

Investors segregate the income and practice mental accounting as they are affected by endowment bias, treat income and capital income alike and also fail to view them as an overall investment.

After thorough assessment of different bias that prevail in stock market, cognitive dissonance and rational behavior are considered for empirical study as these two help understand the influence of decision making in both direct and indirect manner. To understand the same, diversified heuristics are reviewed using available literature in the following paragraphs.

\section{Literature Review and Hypothesis Development}

\subsection{Availability}

Humans have curtailed attentiveness, remembrance and calculation abilities so in this dynamic environment investors are loaded with enormous data and information which complicates to tackle decision making (Tversky, A., \& Kahneman, D., 1973; Andrey, \& Cohen, G., 2012). Individuals assign more credibility to accessible information compared to previous occurrence or knowledge, so the investors assume and that limelight stocks would always be attractive and increase in near future (Tversky, A., \& Kahneman, D., 1974). This bias gives scope for arousal of overreaction due to their unmindful nature and become overconfident in times of contingent situations as they base their prediction on the hand information (Hirshleifer, D. A., 2001). Availability bias makes both investors and professional experts blind fold as they are not able to properly assess the information, figure and occurrence due to absent-mindedness which gives them to attach more significance to the information on hand. (Daniel, K., D. Hirshleifer \& Siew Hong Teoh, 2002)

Availability bias influences investors to park their funds in single specialized market or sector rather than investing in divergent ones. Local market shares are chosen due to home and familiarity bias of investors in general, but more preferred by availability biased investors as information can be procured with ease. Thus availability bias narrow down 
the investor's choices though they are wide-ranging options, as well as miss the right and proper selection of investment avenues. Investors bank on media, recommendations and firms financial statements rather than financial disclosure information. (Le Phuoc Luong \& Doan Thi Thu Ha 2011;Waweru, N. M. Munyoki, E. \& Uliana, E 2008).

Availability bias along with other heuristics evidenced to be strong among individual investors compared to prospect variables.(Chandra \& Kumar, 2008; Daniel et.al, 2002; Baker \& Nofsinger, 2002) studies jointly state that that availability bias is influenced by both cognitive biases and emotional bias.

H1: There is a significant relationship between Availability and Cognitive Dissonance

Among heuristics availability is being taken for the current study as it is observed that stock selection by rational investors is usually based on fundamental, technical, company and industry analysis but the facts and reports received during the selection stage influence causes investors to be prone to availability bias. It can be positively or negatively influence the investment decision making (Massa, M., \& Simonov, A., 2005; Haley, U. C. V., \& Stumpf, S. A., 1989).

$\mathrm{H} 2$ : There is a significant relationship between Availability and Rational Behavior.

\subsection{Cognitive Dissonance Bias}

Leon Festinger propounded this bias in 1957. It is a mental state where an investor feels dilemmatic to take decision between given choices of risk and uncertainties. The investor experiences this dissonance when he faces difference of opinion between the belief they hold and actual facts they come to realize. This bias makes them to battle against their thoughts with their own actions as both seem to contradict one another. This bias accustoms the investor to be selective in their perception as well as their decision making (Festinger L., 1957).

Selective perception is when the investors collect only those facts which accords with their convictions are taken into account. The decisions taken earlier are supported in spite of the proven data or information is false called as Selective Decision making (Pompian, 2012).

Whenever an investor is faced with any latest information that seems to refute his previously assumed belief they do not accept the fact and ignore its prevalence as it is conflicting with our belief and feel sorry later after facing the real fact (Chandra \& Kumar, 2008).

H1: There is a significant relationship between Availability and Cognitive Dissonance

The investor should accepts the flaw change and adapt to make rational decisions and thus reduce the effect of cognitive dissonance. Thus only a change in attitude will reduce the irrational decisions taken due to cognitive dissonance (Sharma, A. J., 2014).

$\mathrm{H} 2$ : There is a significant relationship between Availability and Rational Behavior.

\subsection{Mental Accounting Bias}

It is a bias where investors divide their money into different portions to meet different investment objectives separately as a result of prejudiced decisive factor (Barberis, N., \& Thaler, R. H., 2003; Thaler, 1985). It prevents the funds to being replaced with one another though there are in similar in nature and makes it more rigid (Chopde, S., 2017) for funds to flow (Thaler, 1999). The benefits to be derived from one source is not mixed up with other sources, treatment of cost and benefits from each source is treated separately rather than as a whole. It prevents investors to mitigate risk and loss by amalgamating all sources of income and deploy it for achieving overall return (Pompian, 2012). Few studies have empirically proved the prevalence of this bias (Rekik \& Boujelbene, 2013; Chandra \& Kumar 2008) whereas other studies (Bashir, T., Javed, A, \& Tanveer, A., 2013) have proved it does not affect the investors (K. Lee, Miller. S, Velasquez. N., \& Wann. C.; Subash, 2012) found male investors to be more prone to this bias compared to female investors.(Subash, 2012) proved irrespective of experience level all on whole are impacted by mental accounting bias.

Increased information, intermittent notifications of news and other the readily accessible information on the whole will motivate investors depending on the efficacy of the information. It can also demotivate them to perform financial segregation and planning of mental accounting (Zhang, C. Y., \& Sussman, A., 2018).

H3: There is a significant relationship between Availability and Mental accounting.

It has been proved that mental accounting has a mediating role on individual's financial planning and cognition behavior (Mahapatra, Mousumi, Raveendran, Jayasree \& DeAnupam, 2018). Few studies have emphasized the requirement to focus on both internal and external factors that have an effect on mental accounting bias and find 
circumstances when it becomes operative. Thus we examine mental accounting bias prevalence on intellectual and reasoning of investors (Sussman \& O'Brien, 2016; Soman \& Cheema, 2011).

H4: There is mediation effect of mental accounting bias through availability heuristic on cognitive dissonance.

H5: There is mediation effect of mental accounting bias through availability heuristic on rational behavior of investors

There are many studies which have examined the role of various and bias on investor's decision making ignoring the base that all these cognitive bias leads to cognitive dissonance which is an element for investor's decision making. Among which mental accounting bias and cognitive dissonance is being given less importance so these variables are chosen for our current study. Usually we have many studies for individual investors in volatile stocks and no specific studies are done in defensive sectors like FMCG sector.

\subsection{Objectives}

To examine the role of availability bias in association with mental accounting bias and its influence on cognitive dissonance and rational behavior of FMCG investors.

The role of mental accounting bias on availability heuristic and its influence on cognitive dissonance and rational behavior of FMCG Investors.

\subsection{Hypothesis}

H1: There is a significant relationship between Availability and Cognitive Dissonance

$\mathrm{H} 2$ : There is a significant relationship between Availability and Rational Behavior.

H3: There is a significant relationship between Availability and Mental accounting.

H4: There is mediation effect of mental accounting bias through availability heuristic on cognitive dissonance.

H5: There is mediation effect of mental accounting bias through availability heuristic on rational behavior of investors.

\subsection{Research Model}

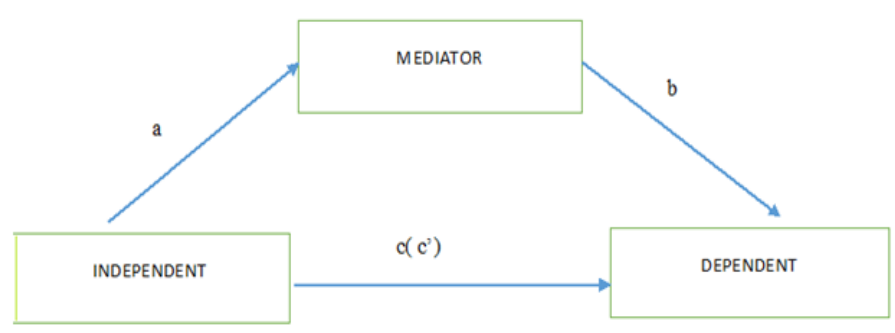

Figure 1. Conceptual framework

Availability (AVAIL) as Independent variable, Mental Accounting (MENAC) bias as a mediating variable, Cognitive Dissonance (COD) and Rational behavior (RB) as Dependent Variable.

Path a-the independent variable effect on the mediating variable

Path b-, the dependent variable effect on independent variable with the mediator

Path c'-the independent variable effect on dependent variable which gives the direct effect

Path c-the dependent variable effect on independent variable which gives the total effect

Indirect Effect $(\mathrm{ab})$ or IDE $=$ independent variable on dependent variable through the mediating variable.

\section{Research Methodology}

\subsection{Sample and Data Collection}

Non Probability sampling technique of purposive sampling was used to distribute the self-administered questionnaire from January 2019 to April 2019.Investors response was collected from 15 registered stock broking firms in 
Hyderabad city. The respondents who invested in the FMCG equity shares in Hyderabad city are only considered as sample for the current study. Out of 800 self-administered questionnaires 614 respondents were received after data cleaning with $77 \%$ response rate.

\subsection{Instrument}

The questionnaire was divided into two parts, demographics and actual testing variables. Demographic information is explained with the help of descriptive statistics and in the second part with questions related to availability, mental accounting, cognitive dissonance biases and rational behavior of investors. Reliability statistics is used to test internal consistency and reliability of the instrument by Cronbach's Alpha coefficient. The value derived is 0.96 (appendices) which is above 0.70 so this implies it can be accepted. The second part respondents availability, cognitive dissonance, mental accounting bias and rational behavior of investors was measured with 21 questions to test their tendency to be influenced and their level of agreement with each type of bias using five point Likert scale with 1 as Strongly agree to 5 as Strongly disagree. How investors decide based on the available information elements like latest news, media prone stocks ,buy new stocks, consult peer, professionals, assurance, performance obtained from (Khan, H. H., Naz, I., Qureshi, F., \& Ghafoor, A, 2017; Bashir et.al 2013; Tversky. A., \& Kahneman, D., 1973). Mental accounting bias tested with questions like using other sources of funds, mixing up of funds, treat as a whole, two separate sources derived from (Aamir, Abid, Usman, Jahanzaib \& Malik, 2018; N. Thaler, 1985). Cognitive dissonance elements tested with elements like hold on, hold contrary views, actions and decision do not match, convince yourself, feel bad, confused, mental stress is obtained from (Sunaina Kanojia, 2018; Aamir et.al. 2018; Subash, 2012; William, N., \& Goetzmann Peles, 1997). Finally rational investment decisions taken by investors is measured based on price track, news, market, fundamental and past performance from Le Phoc Luong Doan Thi Thu Ha 2011.

\subsection{Tools Used}

Correlation analysis is used as we are dealing with psychological variables that help us to know relationship between the variables. Analysis of variance was used to test the significance and variance among the variables. Cronbach Alpha test was used for testing the validity. Linear regression, multiple linear regression was run using Hayes Mediation method (2018) in SPSS version 3.3 Macros Model 4 and the results are inferred. Hayes method 2018 is applied with bootstrapping and percentile method at $95 \%$ confidence interval (CI).

\section{Results and Discussion}

\subsection{Profile of Respondents}

Table 1 exhibits the demographic variables of the respondents. The major percentage of the respondents constitute of 18 to 25 age group (33\%) and 25 to 35 (29\%), followed by 35 to $45(24 \%), 45$ to $55(9 \%)$, and above $55(6 \%)$. The greater part of the FMCG investors are male investors (61\%) and minority of them are female investors (39\%). Respondent's income level is mostly below 1.2 to 3 lakhs $(30 \%)$ and below 1.2 lakhs (22\%) others fall under category of 3 to 5 lakhs (18\%), 5 to 7.5 Lakhs (11\%), Above 10 Lakhs (10.9\%) only few constitute for 7.5lakhs to 10 lakhs $(5 \%)$ per month. Investors are mostly being employed in private sector (49\%) and others (22\%), while remaining are self-employed (20\%) and least are employed in government jobs (9\%). Majority of the respondents are of 1 to 2 years of experience (58\%), 2 to 4 years (16\%), and few with 4 to 6 years (8\%), above 10 years (6\%) and 6 to 8 years $(5 \%)$.

Table 1. Consolidated results of demographic variables

\begin{tabular}{llll}
\hline Demographics & Category & No & $\%$ \\
\hline \multirow{2}{*}{ Gender } & Female & 242 & 39.4 \\
\cline { 2 - 4 } & Male & 372 & 60.6 \\
\hline \multirow{4}{*}{ Age } & $18-25$ & 202 & 32.9 \\
\cline { 2 - 4 } & $25-35$ & 175 & 28.5 \\
\cline { 2 - 4 } & $35-45$ & 146 & 23.8 \\
\cline { 2 - 4 } & $45-55$ & 54 & 8.8 \\
\hline
\end{tabular}




\begin{tabular}{|c|c|c|c|}
\hline \multirow{6}{*}{ Income } & Below 1.2 & 134 & 21.8 \\
\hline & 1.2 to 3 & 184 & 30 \\
\hline & 3 to 5 & 112 & 18.2 \\
\hline & 5 to 7.5 & 70 & 11.4 \\
\hline & 7.5 to 10 & 31 & 5 \\
\hline & Above 10 & 67 & 10.9 \\
\hline \multirow{4}{*}{ Occupation } & Govt & 56 & 9.1 \\
\hline & Private & 300 & 48.9 \\
\hline & Self & 120 & 19.5 \\
\hline & Others & 133 & 21.7 \\
\hline \multirow{6}{*}{ Experience } & 1 to 2 & 357 & 58.1 \\
\hline & 2 to 4 & 97 & 15.8 \\
\hline & 4 to 6 & 52 & 8.5 \\
\hline & 6 to 8 & 33 & 5.4 \\
\hline & 8 to 10 & 20 & 3.3 \\
\hline & Above 10 & 37 & 6 \\
\hline
\end{tabular}

Thus it can be inferred that most of respondents are young investors employed in private sector earning modest amount with fairly limited experience. The returns being low in other investment avenues like fixed deposit, savings bank account people have found no other better alternative to invest and have penetrated to stock market. The recent zero brokerage accounts have successfully led to capture of many young investors to invest in stock market. This can be an encouraging platform to all the stock broking firms as well as investors.

\subsection{Hypothesis Testing}

\subsubsection{Correlation Analysis}

Table 2 displays the descriptive and correlation analysis of variables in our study. Availability bias is highly correlated with Cognitive Dissonance (0.95) Rational Behavior (0.94); and Mental accounting (0.86).

Mental accounting bias is highly correlated with Availability (0.86), Cognitive Dissonance (0.85) and Rational (0.84). Cognitive dissonance is highly correlated with rational (0.95); Availability (0.94) and Mental accounting (0.84).

Table 2. Descriptive analysis and Pearson correlation results $(\mathrm{N}=614)$

\begin{tabular}{lllllll}
\hline Variables & Mean & Std Dev & Availability & Mental & $\begin{array}{l}\text { Cognitive } \\
\text { Dissonance }\end{array}$ & $\begin{array}{l}\text { Rational } \\
\text { Behavior }\end{array}$ \\
\hline Availability & 3.2968 & 1.07349 & - & 0.856 & 0.95 & 0.939 \\
\hline Mental accounting & 3.2926 & 1.14063 & 0.856 & - & 0.845 & 0.840 \\
\hline Cognitive Dissonance & 3.0913 & 0.97938 & 0.950 & 0.845 & - & 0.947 \\
\hline Rational Behavior & 3.4555 & 1.02482 & 0.939 & 0.840 & 0.947 & - \\
\hline
\end{tabular}

It can be inferred that Availability influences Cognitive dissonance as investors usually rely upon the known data and facts for decision making. In the current study, it is proved with the results that availability of information did have influence on investors' investment decision making during the study period. This indicates that, their portfolio decision is also dependent on the information availability and usefulness leading to mitigation of risk. However, under certain circumstance, where respondents are getting information, but is of no use to them while deciding and 
forcing them to a state of dilemma, investors are highly confused, their decisions are ineffective and their portfolio is also getting effected amongst the select sample. However, results are quite contra in case of mental accounting assessments which is due to divergent orientation, risk taking ability, portfolio selection and management and skill of decision making by individuals.

4.2.2 Regression and Mediation Analysis

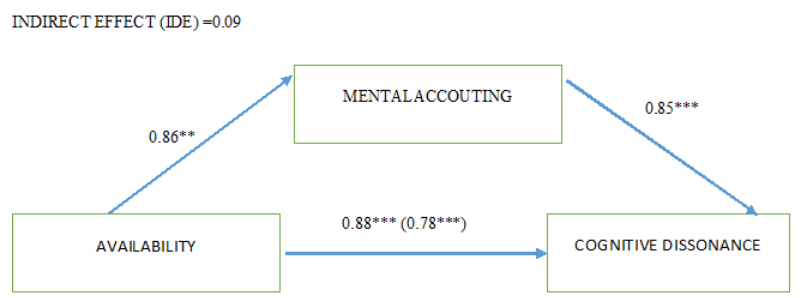

Figure 2. The mediating effect of mental accounting in the relationship between availability and cognitive dissonance

Figure 2 examines the values of path coefficients, direct, total effect and indirect of mediation as per our research model. Regression analysis was used to investigate the hypothesis that mental accounting bias mediates the effect of availability on cognitive dissonance. Mental accounting bias as an outcome provides path a (0.86), a test of statistical significance with $\mathrm{t}=40.9936$, CI $(0.8661$ to 0.9533$), \mathrm{p}<0.01(0.00)$ so it is highly significant. So there is positive correlation between availability and mental accounting (H3). Thus we can conclude the independent variable availability significantly affects the mental accounting bias the mediating variable. Cognitive dissonance as the dependent variable and both availability and mental accounting as predictors provides paths b (0.85) and $\mathrm{c}^{\prime}(0.17)$. The $95 \%$ confidence intervals for these two parameters are created through bootstrapping, where LLCI is the lower limit confidence Interval and ULCI is the upper limit confidence interval are $(0.7329$ to 0.8186$)$ and $(0.0600$ to $0.1406)$ respectively .Total effect $-\mathrm{c}$ path when cognitive dissonance is the only predictor of availability ( 0.95$)$ along with LLCI and ULCI (0.8445 to 0.8896) is significant. There is positive correlation between cognitive dissonance and availability (H1). Mediation effect which is also called as the 'indirect' effect, can be computed as the difference between $c$ and $c^{\prime}$, or as the product of paths a and $b$. With the given bootstrapped confidence interval for the indirect effect of availability on cognitive dissonance through mental accounting is 0.09 . Thus it can be concluded that mental accounting bias mediates the effect of availability on cognitive dissonance of FMCG investors with Indirect Effect of 0.09 (H4).

The results show that the information at hand will influence the choice of stock selection and investment decisions. Availability will lead to cognitive dissonance only when the information does not agree with the investment objective or belief of the investor so to avoid dissonance the investor searches and collects biased information to confirm their belief. So availability with mental accounting being subjective changes from person to person and thus it can influence dissonance in some investor cases and cannot cause dissonance in other investor circumstances. So availability bias through mental accounting bias has almost negligible effect on cognitive dissonance.

\subsubsection{Regression and Mediation Analysis}

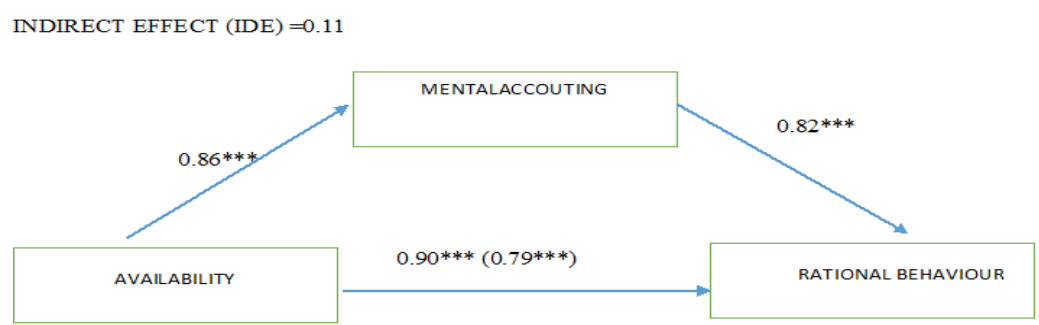

Figure 3. The mediating effect of mental accounting in the relationship between availability and rational behavior 
Figure 3 displays the values of path coefficients, direct, total effect and indirect of mediation as per our research model. Regression analysis was used to investigate the hypothesis that mental accounting bias mediates the effect of availability on rational Behavior. Mental accounting bias as an outcome provides path a (0.86) and a test of statistical significance, $\mathrm{t}=40.9936$, CI $(0.8661$ to 0.9533$), \mathrm{p}<0.01(0.00)$ so highly significant. So there is positive correlation between availability and mental accounting (H3). Rational behavior as the dependent variable and both availability and that mental accounting as predictors provides paths b (0.82) and $c^{\prime}(0.14)$. The $95 \%$ confidence intervals for these two parameters are created through bootstrapping, where LLCI is the lower limit confidence interval and ULCI is the upper limit confidence interval. (0.7364 to 0.8353$)$ and $(0.0750$ to 0.1680$)$ respectively and is significant. Total effect - c path when rational behavior as the only predictor of availability (0.94) along with LLCI and ULCI (0.8703 to $0.9225)$ is significant. There is positive correlation between rational behavior and availability (H2). With the given bootstrapped confidence interval for the indirect effect of availability on rational through mental accounting is 0.11 .Thus it can be concluded that mental accounting bias mediates the effect of availability on rational behavior of FMCG investors with Indirect Effect of 0.11 (H5).

The results explain that availability will influence the rational behavior of the investors as they keep track of the trends, market news, do background study of fundamental and technical analysis before arriving to a decision thus affects their choice of stock selection and investment decisions. It can also leads to confirmation bias, anchoring and underreacting to any new information if it creates dissonance due to contrary information about current stocks in hand or pre-assumed opinion or investment objective. Availability will have lesser relationship with mental accounting compared to rational behavior. Availability bias nature is more of cognitive and information processing type whereas, mental accounting is more of evaluation orientation to divide and calculates cost and benefit from each source separately without assessing it as a whole. Whereas, cognitive dissonance happens only when the first-hand information received affects the portfolio return and investment decisions of mentally divided accounts or contradicts with the separately set goals.

Table 3. Results of mediation analysis

\begin{tabular}{lllllllll}
\hline VARAIBLES & BETA 1 & BETA2 & IDE & R & R & T VALUE & P V at 95 CI & Results \\
\hline AVAIL-MENAC-COD & 0.95 & 0.85 & 0.09 & 0.90 & 0.91 & 35.57 & 0.00 & SIG \\
\hline AVAIL-MENAC-RB & 0.94 & 0.82 & 0.11 & 0.88 & 0.89 & 31.21 & 0.00 & SIG \\
\hline
\end{tabular}

Introduction of Mental accounting as mediating variable reduced the beta of Availability from 0.95 to 0.85 by $10 \%$ and R square variance from 0.90 to 0.91 accounts to about $1 \%$ variance. There was a significant indirect effect of Availability on Cognitive Dissonance through Mental accounting bias is 0.09. Thus Mental Accounting bias mediates effect of Availability on Cognitive Dissonance is concluded (H4).

Introduction of Mental accounting as mediating variable reduced the beta of Availability from 0.94 to 0.82 by $13 \%$ and R square variance from 0.90 to 0.91 accounts to about $1 \%$ variance. There was a significant indirect effect of Availability on rational behavior through mental accounting bias is 0.11 . Thus Mental Accounting bias mediates effect of availability on rational behavior is concluded (H5).

\subsection{Findings Summary}

H1: There is a significant relationship between Availability and Cognitive Dissonance (0.95).

$\mathrm{H} 2$ : There is a significant relationship between Availability and Rational Behavior (0.94).

H3: There is a significant relationship between Availability and Mental accounting (0.86)

H4: There is mediation effect of mental accounting bias through availability heuristic on cognitive dissonance with Indirect Effect is (0.09).

H5: There is mediation effect of mental accounting bias through availability heuristic on rational behavior of investors with Indirect Effect (0.11).

\section{Conclusion}

Availability influences both cognitive dissonance and rational behavior of investors and is highly correlated to one another. But the mediation effect of mental accounting bias through availability heuristic on cognitive dissonance and rational behavior of investors has very negligible indirect effect though it there is high correlation between 
availability and mental accounting. The current study findings are in line with study of Mahapatra, 2018 which evidenced partial mediation effect of mental accounting of financial cognition on Indian households. In general, information enables the investors to clarify evaluation of their mental accounting results and apportionment. Studies and have agreed upon the fact that splitting up the sources of income and certain amount kept aside as reserve to meet personal goals will upsurge the funds and make rational decisions (Soman \& Cheema, 2011). However in US funds kept in reserve were not used during times of difficulty which led to negative results of landing into high credit borrowing due to mental accounting and irrational decisions (Sussman \& O'Brien, 2016). So mental accounting bias has its own advantages of meeting goals and disadvantages of making irrational decisions.

Based on first-hand information practicing mental accounting will give them a cue about their limits within which they can plan out for each investment goal or warn them about their own financial shortage to be faced in future, which aids them to take rational decisions (Zhang, C, Y., \& Sussman, A. B., 2018). Thus mediation effect of mental accounting through availability bias on rational behavior is higher compared to its indirect effect on cognitive dissonance.

But investors who do not want to encounter with warning signs or inadequacies of their finances avoid such information to prevent dissonance or consider them as irrelevant information. Thus cognitive dissonance happens only when the first-hand information received affects the portfolio return and investment decisions of mentally divided accounts or contradicts with the separately set goals. We can conclude that availability bias through mental accounting bias has almost negligible effect on cognitive dissonance in case of FMCG investors. Mental accounting is self-governing in nature and distinct from person to person thus it can influence dissonance in some cases and cannot cause dissonance in other circumstances. The present study is limited to a particular region and sector this can be extended in future to measure and explore the mediation effect along with other heuristics, biases and decision making variables. Future studies can explore to find out under which circumstances does it plays an effective role.

\section{References}

Ackert, L., Church, B., \& Deaves, R. (2003). Emotion and financial markets. Economic Review-Federal Reserve Bank of Atlanta, 2, 33-41. Retrieved https://EconPapers.repec.org/RePEc:fip:fedaer:y:2003:i:q2:p:33-41:n:v.88no.2

Baker, H. K., \& Nofsinger, J. R. (2002). Psychological Biases of Investors. Financial Service Review, 11(1), 97-116.

Barberis, N., \& Thaler, R. H. (2003). A Survey of Behavioral Finance. Handbook of the Economics of Finance Elsevier Science, BV(1), 1051-112. Retrieved from https://EconPapers.repec.org/RePEc:nbr:nberwo:9222

Bashir, T., Javed, A., \& Tanveer, A. (2013). An assessment study on the Factors influencing the individual investor decision making behavior. IOSR Journal of Business and Management, 9(5), 37-44.

Chandra, A., \& Kumar, R. (2008). Factors Influencing Indian Individual Investor Behaviour: Survey Evidence (pp. $1-41)$.

Chopde, S. (2017). Impact of Behavioral Biases on Investment Decisions of Individual Investors in Mumbai - A Sample Study. Proceedings from International Conference on Emanations in Modern Technology and Engineering.

Daniel, K., Hirshleifer, D., \& Teoh, S. H. (2002). Investor Psychology in Capital Markets: Evidence and Policy Implications. Journal of Monetary Economics, 49, 139-209. Retrieved from https://EconPapers.repec.org/RePEc:eee:moneco:v:49:y:2002:i:1:p:139-209

Festinger, L. (1957). A theory of cognitive dissonance. Stanford, CA: Stanford University Press.

Haley, U. C. V., \& Stumpf, S. A. (1989). Cognitive Trials in Strategic Decision making: Linking Theories of Personalities and Cognitions. Journal of Management Studies, 26(5), 477-497. https://doi.org/10.1111/j.1467-6486.1989.tb00740.x

Hirshleifer, D. A. (2001). Investor Psychology and Asset Pricing. SSRN Electronic Journal. https://doi.org/10.2139/ssrn.265132

Hon-Snir, S., Kudryavtsev, A., \& Cohen, G. (2012). Stock Market Investors: Who Is More Rational, and Who Relies on Intuition. International Journal of Economics and Finance, 4(5). https://doi.org/10.5539/ijef.v4n5p56

Khan, H. H., Naz, I., Qureshi, F., \& Ghafoor, A. (2017). Heuristics and Stock Buying Decision: Evidence from Malaysian and Pakistani Stock Markets. Borsa Istanbul Review. https://doi.org/10.1016/j.bir.2016.12.002 
Lee, K. K., Miller, S., Velasquez, N., \& Wann, C. (2013). The Effecct of Investor Bias and Gender on Potfolio Performance and Risk. International Journal of Business and Finance Research, 7(1), 1-16. Retrieved from https://pdfs.semanticscholar.org/18fb/7982c451d0983e12da333378f0a74cf263f4.pdf

Luong, L. P., \& Ha, D. T. T. (2011). Behavioral factors influencing individual investors' decision-making and performance. A Survey at the Ho Chi Minh Stock Exchange (p. 103). Umea School of Business, China. Retrieved from https://www.diva-portal.org/smash/get/diva2:423263/FULLTEXT02.pdf

Mahapatra, M., Raveendran, J., \& De, A. (2018). Mediating Role of Mental Accounting in between Financial Cognition and Personal Financial Planning of Indian Households Academic Research Colloquium for Financial Planning and Related Disciplines. https://doi.org/10.2139/ssrn.3257860

Massa, M., \& Simonov, A. (2005). Behavioral biases and investment. Review of Finance, 9(4), 483-507.

Pompian, M. (2012). Behavioral Finance and Investor Types (pp. 93-117). John Wiley \& Sons, Inc.

Rekik, Y. M., \& Boujelbene, Y. (2013). Determinants of Individual Investor's Behaviors : Evidence from Tunisian Stock Market. IOSR Journal of Business and Management, 8(2), 109-119.

Shahid, M. N., Sabir, S., Abbas, A., Abid, U., \& Jahanzaib, M. (2018). The impact of Behavior biases on investor decisions: Evidence from Pakistan. Journal of Organizational Behavior Research Cilt, 3(2), 45-55.

Sharma, A. J. (2014). Understanding Cognitive Dissonance - The Behavioural Finance Principle. International Journal of Commerce, Business and Management, $3(1)$. https://www.iracst.org/ijcbm/papers/vol3no12014/4vol3no1.pdf

Soman, D., \& Cheema, A. (2011). Earmarking and partitioning: Increasing saving by low-income households. Journal of Marketing Research, XL(VIII), S14-S22. Retrieved from http://www2.rotman.utoronto.ca/facbios/file/earmarking-jmrPP.pdf

Subash, R. (2012). Role of behavioral finance in portfolio investment decisions: Evidence from India. Charles University in Prague Faculty of Social Sciences Institute of Economic Studies.

Sussman, A. B., \& O'Brien, R. L. (2016). Knowing when to spend: Unintended financial consequences of earmarking to encourage savings. Journal of Marketing Research, 53, 790-803. https://doi.org/10.1509/jmr.14.0455

Thaler, R. (1985). Mental accounting and consumer choice. Marketing Science, 4(3), 199-214. https://doi.org/10.1287/mksc.4.3.199

Thaler, R. (1999). Mental Accounting Matters. Journal of Behavioral Decision Making, (12), 183-206. https://doi.org/10.1002/(SICI)1099-0771(199909)12:3<183::AID-BDM318>3.0.CO;2-F

Tversky, A., \& Kahneman, D. (1973). Availability: A heuristic for judging frequency and probability. Cognitive Psychology, 5(2), 207-232.

Tversky, A., \& Kahneman, D. (1974). Judgment under uncertainty: Heuristics and biases. Science, 185(4157), 1124-1131. Retrieved from http://psiexp.ss.uci.edu/research/teaching/Tversky_Kahneman_1974.pdf

Waweru, N. M., Munyoki, E., \& Uliana, E. (2008). The effects of behavioral factors in Nairobi Stock Exchange. International Journal of Business and Emerging Markets, 1(1), 24-41.

William, N., \& Peles, G. (1997). Cognitive Dissonance and Mutual Fund Investors. The Journal of Financial Research, 20(2), 1145-158, https://doi.org/10.1111/j.1475-6803.1997.tb0024 .x

Zhang, C. Y., \& Sussman, A. B. (2018). Perspectives on mental accounting: An exploration of budgeting and investing. Financial Planning Review. https://doi.org/10.1002/cfp2.1011 


\section{Appendices}

Table 1. Descriptive statistics

\begin{tabular}{llll} 
& Mean & Std. Deviation & $\mathrm{N}$ \\
\hline AVAIL & 3.2968 & 1.07349 & 614 \\
\hline MENAC & 3.2926 & 1.14063 & 614 \\
\hline COD & 3.0913 & .97938 & 614 \\
\hline RATIONAL & 3.4555 & 1.02482 & 614 \\
\hline
\end{tabular}

Table 2. Reliability statistics

\begin{tabular}{ll}
\hline Cronbach's Alpha N of Items \\
\hline .970 & 4 \\
\hline
\end{tabular}

Table 3. Correlations

\begin{tabular}{|c|c|c|c|c|c|}
\hline & & AVAIL & MENAC & COD & RATIONAL \\
\hline \multirow{3}{*}{ AVAIL } & Pearson Correlation & 1 & $.856^{* *}$ & $.950^{* *}$ & $.939^{* *}$ \\
\hline & Sig. (2-tailed) & & .000 & .000 & .000 \\
\hline & $\overline{\mathrm{N}}$ & 614 & 614 & 614 & 614 \\
\hline \multirow{3}{*}{ MENAC } & Pearson Correlation & $.856^{* *}$ & 1 & $.845^{* *}$ & $.840^{* *}$ \\
\hline & Sig. (2-tailed) & .000 & & .000 & .000 \\
\hline & $\mathrm{N}$ & 614 & 614 & 614 & 614 \\
\hline \multirow{3}{*}{ COD } & Pearson Correlation & $.950^{* *}$ & $.845^{* *}$ & 1 & $.947^{* *}$ \\
\hline & Sig. (2-tailed) & .000 & .000 & & .000 \\
\hline & $\mathrm{N}$ & 614 & 614 & 614 & 614 \\
\hline \multirow{3}{*}{ RATIONAL } & Pearson Correlation & $.939^{* *}$ & $.840^{* *}$ & $.947^{* *}$ & 1 \\
\hline & Sig. (2-tailed) & .000 & .000 & .000 & \\
\hline & $\mathrm{N}$ & 614 & 614 & 614 & 614 \\
\hline
\end{tabular}

Oneway ANOVA with Cognitive dissonance as Dependent Variable

Table 4. ANOVA

\begin{tabular}{|c|c|c|c|c|c|c|}
\hline & & Sum of Squares & $\mathrm{df}$ & Mean Square & $\mathrm{F}$ & Sig. \\
\hline \multirow{3}{*}{ AVAIL } & Between Groups & 649.631 & 54 & 12.030 & 118.432 & .000 \\
\hline & Within Groups & 56.783 & 559 & .102 & & \\
\hline & Total & 706.414 & 613 & & & \\
\hline \multirow{3}{*}{ MENAC } & Between Groups & 613.843 & 54 & 11.367 & 34.592 & .000 \\
\hline & Within Groups & 183.695 & 559 & .329 & & \\
\hline & Total & 797.538 & 613 & & & \\
\hline
\end{tabular}

Oneway ANOVA with Rational as Dependent Variable 
Table 5. ANOVA

\begin{tabular}{|c|c|c|c|c|c|c|}
\hline & & Sum of Squares & $\mathrm{df}$ & Mean Square & $\mathrm{F}$ & Sig. \\
\hline & Between Groups & 644.224 & 47 & 13.707 & 124.749 & .000 \\
\hline \multirow[t]{3}{*}{ AVAIL } & Within Groups & 62.190 & 566 & .110 & & \\
\hline & Total & 706.414 & 613 & & & \\
\hline & Between Groups & 604.382 & 47 & 12.859 & 37.681 & .000 \\
\hline \multirow[t]{2}{*}{ MENAC } & Within Groups & 193.156 & 566 & .341 & & \\
\hline & Total & 797.538 & 613 & & & \\
\hline
\end{tabular}

Output 1: Simple mediation analysis output from the PROCESS Macros in SPSS 20 (version 3.3) for the Availability, Mental Accounting and Cognitive Dissonance

Run Matrix Procedure:

$* * * * * * * * * * * * * * *$ PROCESS Procedure for SPSS Version $3.3 * * * * * * * * * * * * * * * * * * *$

**********************************************************************************

Model: 4

Y: COD

$\mathrm{X}:$ AVAIL

M: MENAC

Sample

Size: 614

$* * * * * * * * * * * * * * * * * * * * * * * * * * * * * * * * * * * * * * * * * * * * * * * * * * * * * * * * * * * * * * * * * * * * * * * * * *$

Outcome Variable:

MENAC

Model Summary

$\begin{array}{ccccccc}\mathrm{R} & \mathrm{R} \text {-sq. } & \mathrm{MSE} & \mathrm{F} & \mathrm{df1} & \mathrm{df} 2 & \mathrm{p} \\ .8562 & .7330 & .3479 & 1680.4719 & 1.0000 & 612.0000 & .0000\end{array}$

Model

$\begin{array}{lcccccr} & \text { coeff } & \mathrm{se} & \mathrm{t} & \mathrm{p} & \text { LLCI } & \text { ULCI } \\ \text { constant } & .2935 & .0769 & 3.8143 & .0002 & .1424 & .4446 \\ \text { AVAIL } & .9097 & .0222 & 40.9936 & .0000 & .8661 & .9533\end{array}$

Standardized coefficients

coeff

AVAIL $\quad .8562$

\footnotetext{
$* * * * * * * * * * * * * * * * * * * * * * * * * * * * * * * * * * * * * * * * * * * * * * * * * * * * * * * * * * * * * * * * * * * * * * * * * * *$
}

OUTCOME VARIABLE:

COD 
Model Summary

$\begin{array}{ccccccc}\mathrm{R} & \mathrm{R}-\mathrm{sq} & \mathrm{MSE} & \mathrm{F} & \mathrm{df} 1 & \mathrm{df} 2 & \mathrm{p} \\ .9523 & .9068 & .0897 & 2972.3505 & 2.0000 & 611.0000 & .0000\end{array}$

Model

$\begin{array}{lcccccc} & \text { coeff } & \mathrm{se} & \mathrm{t} & \mathrm{p} & \text { LLCI } & \text { ULCI } \\ \text { constant } & .2035 & .0395 & 5.1484 & .0000 & .1259 & .2811 \\ \text { AVAIL } & .7758 & .0218 & 35.5723 & .0000 & .7329 & .8186 \\ \text { MENAC } & .1003 & .0205 & 4.8878 & .0000 & .0600 & .1406\end{array}$

Standardized coefficients

$\begin{array}{ll} & \text { coeff } \\ \text { AVAIL } & .8503 \\ \text { MENAC } & .1168\end{array}$

$* * * * * * * * * * * * * * * * * * * * * * * * * *$ TOTAL EFFECT MODEL $* * * * * * * * * * * * * * * * * * * * * * * * * * * *$

OUTCOME VARIABLE:

COD

Model Summary

$\begin{array}{ccccccc}\mathrm{R} & \mathrm{R}-\mathrm{sq} & \mathrm{MSE} & \mathrm{F} & \mathrm{df} 1 & \mathrm{df2} & \mathrm{p} \\ .9503 & .9032 & .0930 & 5707.3426 & 1.0000 & 612.0000 & .0000\end{array}$

Model

$\begin{array}{lcccccc} & \text { coeff } & \mathrm{se} & \mathrm{t} & \mathrm{p} & \text { LLCI } & \text { ULCI } \\ \text { constant } & .2329 & .0398 & 5.8544 & .0000 & .1548 & .3111 \\ \text { AVAIL } & .8670 & .0115 & 75.5470 & .0000 & .8445 & .8896\end{array}$

Standardized coefficients

coeff

*************** TOTAL, DIRECT, AND INDIRECT EFFECTS OF X ON Y $* * * * * * * * * * * * * *$

Total effect of X on $\mathrm{Y}$

$\begin{array}{cccccccc}\text { Effect } & \mathrm{se} & \mathrm{t} & \mathrm{p} & \text { LLCI } & \text { ULCI } & \text { c_ps } & \text { c_cs } \\ .8670 & .0115 & 75.5470 & .0000 & .8445 & .8896 & .8853 & .9503\end{array}$

Direct effect of $\mathrm{X}$ on $\mathrm{Y}$

$\begin{array}{rccccccc}\text { Effect } & \mathrm{se} & \mathrm{t} & \mathrm{p} & \text { LLCI } & \text { ULCI } & \text { c'_ps } & \text { c'_cs } \\ .7758 & .0218 & 35.5723 & .0000 & .7329 & .8186 & .7921 & .8503\end{array}$


Indirect effect(s) of $\mathrm{X}$ on $\mathrm{Y}$ :

$\begin{array}{lllcl} & \text { Effect } & \text { BootSE } & \text { BootLLCI } & \text { BootULCI } \\ \text { MENAC } & .0913 & .0320 & .0316 & .1570\end{array}$

Partially standardized indirect effect(s) of $\mathrm{X}$ on $\mathrm{Y}$ :

$\begin{array}{ccccc} & \text { Effect } & \text { BootSE } & \text { BootLLCI } & \text { BootULC } \\ \text { MENAC } & .0932 & .0327 & .0318 & .1594\end{array}$

Completely standardized indirect effect(s) of X on Y:

$\begin{array}{ccccc} & \text { Effect } & \text { BootSE } & \text { BootLLCI } & \text { BootULCI } \\ \text { MENAC } & .1000 & .0352 & .0347 & .1717\end{array}$

$* * * * * * * * * * * * * * * * * * * * * * *$ ANALYSIS NOTES AND ERRORS $* * * * * * * * * * * * * * * * * * * * * * * *$

Level of confidence for all confidence intervals in output:

95.0000

Number of bootstrap samples for percentile bootstrap confidence intervals:

5000

------ END MATRIX -----

Ouput 2: Simple mediation analysis output from the PROCESS Macros in SPSS (version 3.3) for the Availability, Mental Accounting and Rational Behaviour.

Run MATRIX procedure:

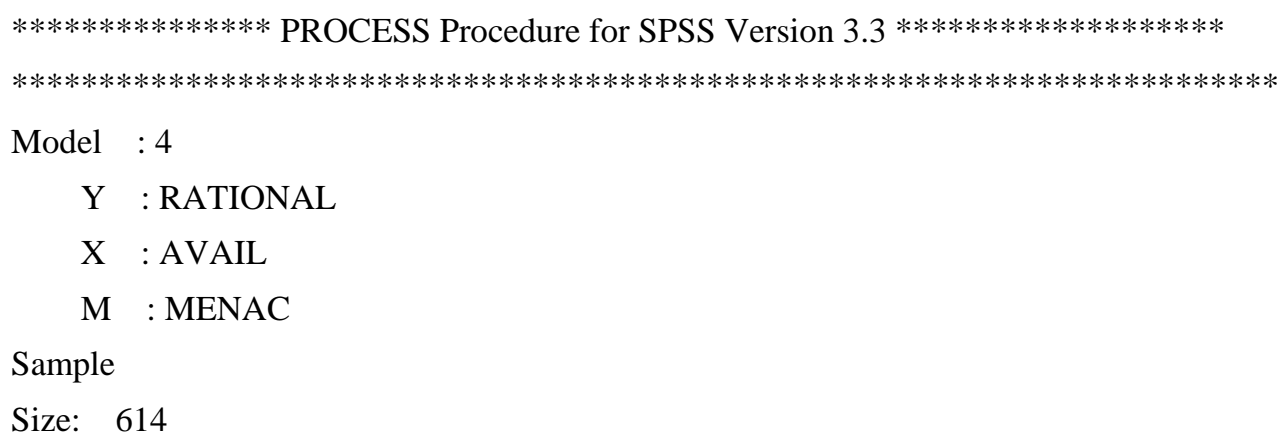

Sample

Size: 614

$* * * * * * * * * * * * * * * * * * * * * * * * * * * * * * * * * * * * * * * * * * * * * * * * * * * * * * * * * * * * * * * * * * * * * * * * * * *$

\section{OUTCOME VARIABLE:}

MENAC

Model Summary

$\begin{array}{ccccccc}\mathrm{R} & \mathrm{R}-\mathrm{sq} & \text { MSE } & \mathrm{F} & \mathrm{df} 1 & \mathrm{df} 2 & \mathrm{p} \\ .8562 & .7330 & .3479 & 1680.4719 & 1.0000 & 612.0000 & .0000\end{array}$

Model 


$\begin{array}{lcccccc} & \text { coeff } & \mathrm{se} & \mathrm{t} & \mathrm{p} & \text { LLCI } & \text { ULCI } \\ \text { constant } & .2935 & .0769 & 3.8143 & .0002 & .1424 & .4446 \\ \text { AVAIL } & .9097 & .0222 & 40.9936 & .0000 & .8661 & .9533\end{array}$

Standardized coefficients

coeff

AVAIL $\quad .8562$

$* * * * * * * * * * * * * * * * * * * * * * * * * * * * * * * * * * * * * * * * * * * * * * * * * * * * * * * * * * * * * * * * * * * * * * * * * * *$

\section{OUTCOME VARIABLE:}

RATIONAL

Model Summary

$\begin{array}{ccccccc}\mathrm{R} & \mathrm{R}-\mathrm{sq} & \mathrm{MSE} & \mathrm{F} & \mathrm{df} 1 & \mathrm{df} 2 & \mathrm{p} \\ .9416 & .8865 & .1196 & 2386.8786 & 2.0000 & 611.0000 & .0000\end{array}$

Model

$\begin{array}{lcccccc} & \text { coeff } & \mathrm{se} & \mathrm{t} & \mathrm{p} & \text { LLCI } & \text { ULCI } \\ \text { constant } & .4647 & .0456 & 10.1820 & .0000 & .3750 & .5543 \\ \text { AVAIL } & .7859 & .0252 & 31.2108 & .0000 & .7364 & .8353 \\ \text { MENAC } & .1215 & .0237 & 5.1270 & .0000 & .0750 & .1680\end{array}$

Standardized coefficients

$\begin{array}{ll} & \text { coeff } \\ \text { AVAIL } & .8232 \\ \text { MENAC } & .1352\end{array}$

******************************** TOTAL EFFECT MODEL $* * * * * * * * * * * * * * * * * * * * * * * * * * * *$

OUTCOME VARIABLE:

\section{RATIONAL}

Model Summary

$\begin{array}{lcccccc}\mathrm{R} & \mathrm{R}-\mathrm{sq} & \mathrm{MSE} & \mathrm{F} & \mathrm{df1} & \mathrm{df} 2 & \mathrm{p} \\ .9390 & .8817 & .1245 & 4559.1034 & 1.0000 & 612.0000 & .0000\end{array}$

Model

$\begin{array}{lcccccc} & \text { coeff } & \mathrm{se} & \mathrm{t} & \mathrm{p} & \text { LLCI } & \text { ULCI } \\ \text { constant } & .5003 & .0460 & 10.8705 & .0000 & .4099 & .5907 \\ \text { AVAIL } & .8964 & .0133 & 67.5211 & .0000 & .8703 & .9225\end{array}$

Standardized coefficients 
coeff

AVAIL $\quad .9390$

$* * * * * * * * * * * * * *$ TOTAL, DIRECT, AND INDIRECT EFFECTS OF X ON Y $* * * * * * * * * * * * * *$

Total effect of $\mathrm{X}$ on $\mathrm{Y}$

$\begin{array}{cccccccc}\text { Effect } & \mathrm{se} & \mathrm{t} & \mathrm{p} & \text { LLCI } & \text { ULCI } & \mathrm{c} \_p s & \text { c_cs } \\ .8964 & .0133 & 67.5211 & .0000 & .8703 & .9225 & .8747 & .9390\end{array}$

Direct effect of $\mathrm{X}$ on $\mathrm{Y}$

$\begin{array}{lccccccc}\text { Effect } & \mathrm{se} & \mathrm{t} & \mathrm{p} & \text { LLCI } & \text { ULCI } & \text { c'_ps } & \text { c'_cs } \\ .7859 & .0252 & 31.2108 & .0000 & .7364 & .8353 & .7668 & .8232\end{array}$

Indirect effect(s) of $\mathrm{X}$ on $\mathrm{Y}$ :

$\begin{array}{ccccc} & \text { Effect } & \text { BootSE } & \text { BootLLCI } & \text { BootULCI } \\ \text { MENAC } & .1105 & .0330 & .0474 & .1783\end{array}$

Partially standardized indirect effect(s) of X on Y:

$\begin{array}{ccccc} & \text { Effect } & \text { BootSE } & \text { BootLLCI } & \text { BootULCI } \\ \text { MENAC } & .1078 & .0322 & .0465 & .1746\end{array}$

Completely standardized indirect effect(s) of X on Y:

$\begin{array}{ccccc} & \text { Effect } & \text { BootSE } & \text { BootLLCI } & \text { BootULCI } \\ \text { MENAC } & .1158 & .0347 & .0490 & .1870\end{array}$

************************* ANALYSIS NOTES AND ERRORS $* * * * * * * * * * * * * * * * * * * * * * * *$

Level of confidence for all confidence intervals in output:

95.0000

Number of bootstrap samples for percentile bootstrap confidence intervals:

5000

------ END MATRIX ----- 